\title{
Protection of dental teams and patients in the COVID-19 era
}

\author{
Jaime A. Teixeira da Silva ${ }^{1 *}$, Aceil Al-Khatib ${ }^{2}$
}

\section{AFFILIATION:}

\section{Jaime A. Teixeira da Silva}

P. O. Box 7, Miki-cho post office, Ikenobe 3011-2, Kagawa-ken, 761-0799, Japan; jaimetex@yahoo.com

\section{Aceil Al-Khatib}

Faculty of Dentistry, Jordan University of Science and Technology, P.O. Box 3030, Irbid 22110, Jordan; aceil@hotmail.com

\section{Article info.}

Received: 7 June 2020

Accepted: 18 June 2020

Volume: 10, Issue-2 ; October 2020

DOI:https://doi.org/10.3329/updcj.v10i2.50171

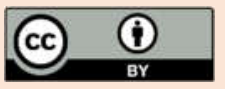

(c) Authors retain copyright and grant the journal right of first publication with the work simultaneously licensed under Creative Commons Attribution License CC - BY 4.0 that allows others to share the work with an acknowledgment of the work's authorship and initial publication in this journal.

https://creativecommons.org/licenses/by/4.0/

Publisher: Update Dental College, Dhaka, Bangladesh

Web: www.updatedentalcollege.edu.bd

E-mail: updcj@hotmail.com

$$
\begin{aligned}
& \text { * Corresponding Author } \\
& \text { Jaime A. Teixeira da Silva } \\
& \text { P. O. Box 7, Miki-cho post office, } \\
& \text { Ikenobe 3011-2, } \\
& \text { Kagawa-ken, 761-0799, Japan; } \\
& \text { jaimetex@yahoo.com }
\end{aligned}
$$

Jaime A. Teixeira da Silva, Aceil Al-Khatib. Protection of dental teams and patients in the COVID-19 era. UpDCJ 2020;10(2):1-2

DOI: https://doi.org/10.3329/updcj.v10i2.50171
Coronavirus Disease 2019 (COVID-19), an airborne transmissible disease caused by the SARS-CoV-2 virus with an incubation period of about 2-14 days, can remain as air droplets and aerosols ${ }^{1}$, or transmitted as conjunctival, nasal, or oral mucosa, via coughing, sneezing, talking and saliva ${ }^{2,3}$, aerosols ${ }^{4}$, or even contact with eyes ${ }^{5}$. These may be important factors to consider where there is close face-to-face contact between a doctor/dentist and a patient. Medical staff and practitioners in contact with an infected patient that may be asymptomatic but infectious nonetheless ${ }^{6}$, may be at a risk of contracting COVID-19. In fact, healthcare workers (HCWs) are being directly impacted. One of the risks and concerns is that HCWs, including dental health care personnel (DHCP), may themselves transmit the virus to other HCWs, DHCP, patients or members of the public.

Drawing on available literature and published advice, this letter attempts to succinctly highlight necessary preventive strategies $^{2}$ and key infection control and prevention precautions required for DHCP, including dentists and oral hygienists, their practices, and their patients, during this pandemic, generally, and beyond. Peng et al. ${ }^{7}$ draw attention to three aspects: 1 ) the use and type of personal protective equipment (PPE) by DHCP; 2) sanitary conditions of operating or treatment rooms and equipment; 3 ) triage, screening and risk assessment of patients during the time of the COVID-19 pandemic. COVID-19 has a higher transmissibility than Severe Acute Respiratory Syndrome (SARS) ${ }^{8}$, so it is useful, prior to initial physical contact with a patient, to employ teledentistry or remote screening via mobile phones to screen and ascertain the dental-related problems, and to determine if a patient displays any COVID-19-related symptoms such as fever, coughing, sore throat, or shortness of breath, i.e., patient evaluation and cohorting ${ }^{7,9}$. To reduce risks to DHCP, patients and the public, non-emergency dental-related problems and elective procedures could be delayed until the pandemic has died down, fortified by official lockdowns to ensure social distancing, which may also impact DHCP financially. Extra-oral radiographs (e.g., panoramic radiographs or cone beam CT) should be used to avoid salivation and coughing that may be induced by intraoral techniques ${ }^{10}$.

As one PPE, face masks (for the general public) and surgical masks (for doctors and DHCP) are at the frontline of the battle against COVID-19, serving as a physical shield fortified by the use of a face shield - that offer one line of protection to both practitioners and patients ${ }^{9}$, although different makers and designs will show different efficacies as a function of their material, porosity, tight-fittingness, thickness, and other parameters ${ }^{11}$. COVID-19 can survive on different 
inanimate surfaces (i.e., fomites) for different periods of time, including paper, plastic, wood, glass and stee ${ }^{12}$, materials that are used by DHCP in dentistry practices in the form of equiment and utensils. Commercial or hospital-grade disinfectants can effectively kill COVID-199.

Peng et al. ${ }^{7}$ also recommend the following precautions and actions, although none of them appear to have been clinically tested for their effectiveness with COVID-19: 1) rinsing the mouth before a dental procedure, and where chlorhexidine might not be effective, " $1 \%$ hydrogen peroxide or $0.2 \%$ povidone is recommended, for the purpose of reducing the salivary load of oral microbes, including potential 2019-nCoV carriage" (p. 4); 2) use of a rubber dam to "minimize the production of saliva- and blood-contaminated aerosol or spatter" (p. 4); 3) use of an anti-retraction highspeed dental hand-piece to reduce the backflow of oral bacteria and to prevent the cross-contamination of air and water tubes; 4) effective management (pretreatment, cleansing, sterilization, and storage) of medical waste. Meng et al. ${ }^{10}$ also point out the importance of dental education as a long-term preventive action. This should always take place within continuous and strict ethical guidelines. Strict governmental policies will allow dental associations to manage COVID-19 infection in oral diagnosis and treatment ${ }^{13}$, so compliance with policies and the practice of universal infection control measures should minimize transmission of SARS-CoV2 in the dental environment. During the COVID-19 pandemic, it is important to increase awareness of COVID-19 transmission routes and preventative measures that are in place, as this will address the concerns of dental patients who might hesitate to seek urgent dental treatments out of fear of contracting the virus, taking it home, or spreading the disease.

\section{REFERENCES:}

1. Wang J, Du G. COVID-19 may transmit through aerosol. Ir J Med Sci 2020;189:1143-1144 doi: $\quad 10.1007 / \mathrm{s} 11845-020-02218-2$ https://doi.org/10.1007/s11845-020-02218-2

PMid:32212099 PMCid:PMC7094991

2. Sabino-Silva R, Jardim ACG, Siqueira WL. Coronavirus COVID-19 impacts to dentistry and potential salivary diagnosis. Clin Oral Invest 2020;24:1619-1621. doi: 10.1007/s00784-020-03248-x https://doi.org/10.1007/s00784-020-03248-x

PMid:32078048 PMCid:PMC7088419

3. To KK-W, Tsang OT-Y, Yip CC-Y, et al. Consistent detection of 2019 novel coronavirus in saliva. Clin Infect Diseases, ciaa149 ciaa149. 2020;71(15):841-843.doi: 10.1093/cid/ciaa149

https://doi.org/10.1093/cid/ciaa149

PMid:32047895 PMCid:PMC7108139

4. van Doremalen N, Bushmaker T, Morris DH, et al. Aerosol and surface stability of SARS-CoV-2 as compared with SARS-CoV-1. N Engl J Med 2020;382:1564-1567. doi: 10.1056/NEJMc2004973 https://doi.org/10.1056/NEJMc2004973 PMid:32182409 PMCid:PMC7121658

5. Lu C-W, Liu X-F, Jia Z-F. 2019-nCoV transmission through the ocular surface must not be ignored. The Lancet 2020;395(10224):E39. doi: 10.1016/S0140-6736(20)30313-5 https://doi.org/10.1016/S0140-6736(20)30313-5

6. Rothe C, Schunk M, Sothmann P, et al. Transmission of 2019$\mathrm{nCoV}$ infection from an asymptomatic contact in Germany. N Engl J Med 2020;382(10):970-971. doi: 10.1056/NEJMc2001468 https://doi.org/10.1056/NEJMc2001468
PMid:32003551 PMCid:PMC7120970

7. Peng $X, X u X, L i Y-Q$, et al. Transmission routes of 2019-nCoV and controls in dental practice. Int J Oral Sci 2020;12(1):9. doi:10.1038/s41368-020-0075-9

https://doi.org/10.1038/s41368-020-0075-9 PMid:32127517 PMCid:PMC7054527

8. Wilder-Smith A, Chiew CJ, Lee VJ. Can we contain the COVID-19 outbreak with the same measures as for SARS? Lancet Infect Dis 2020;20(5):E102-E107.doi:10.1016/S1473-3099(20)30129-8 https://doi.org/10.1016/S1473-3099(20)30129-8

9. Ather A, Patel B, Ruparel NB, et al. Coronavirus Disease 19 (COVID-19): implications for clinical dental care. J Endodontics 2020;46(5):584-595. doi:10.1016/j.joen.2020.03.008 https://doi.org/10.1016/j.joen.2020.03.008 PMid:32273156 PMCid:PMC7270628

10. Meng L, Hua F, Bian Z. Coronavirus Disease 2019 (COVID-19): emerging and future challenges for dental and oral medicine. $J$ Dent Res 2020;99(5):481-487. doi: 10.1177/0022034520914246 https://doi.org/10.1177/0022034520914246 PMid:32162995 PMCid:PMC7140973

11. Wax RS, Christian MD. Practical recommendations for critical care and anesthesiology teams caring for novel coronavirus (2019nCoV) patients. Can J Anesthesia 2020;67:568-576. doi: 10.1007/s12630-020-01591-x https://doi.org/10.1007/s12630-020-01591-x PMid:32052373 PMCid:PMC7091420

12. Kampf G, Todt D, Pfaender S, Steinmann E. Persistence of coronaviruses on inanimate surfaces and its inactivation with biocidal agents. J Hosp Infect 2020;104(3):246-251. doi:10.1016/j.jhin.2020.01.022 https://doi.org/10.1016/i.jhin.2020.01.022 PMid:32035997 PMCid:PMC7132493

13. Spagnuolo G, De Vito D, Rengo S, Tatullo M. COVID-19 outbreak: an overview on dentistry. Int J Env Res Publ Health 2020;17:2094. doi:10.3390/ijerph17062094

https://doi.org/10.3390/ijerph17062094 PMid:32235685 PMCid:PMC7143628 